Article

\title{
A Redneck Head on a Nazi Body. Subversive Ludo-Narrative Strategies in Wolfenstein II: The New Colossus
}

\author{
Hans-Joachim Backe
}

Center for Computer Games Research, IT University of Copenhagen, 2300 Copenhagen, Denmark; hanj@itu.dk

Received: 13 July 2018; Accepted: 19 October 2018; Published: 6 November 2018

\begin{abstract}
This article argues that Wolfenstein: The New Colossus, a AAA First-Person Shooter, is not only politically themed, but presents in itself a critical engagement with the politics of its genre and its player base. Developed at the height of \#Gamergate, the game is interpreted as a response to reactionary discourses about gender and ability in both mainstream games and the hardcore gamer community. The New Colossus replaces affirmation of masculine empowerment with intersectional ambiguities, foregrounding discourses of feminism and disability. To provoke its players without completely alienating them, the game employs strategies of carnivalesque aesthetics-especially ambivalence and grotesque excess. Analyzing the game in the light of Bakhtinian theory shows how The New Colossus reappropriates genre conventions pertaining to able-bodiedness and masculinity and how it "resolves" these issue by grafting the player character's head on a vat-grown Nazi supersoldier-body. The breaches of genre conventions on the narrative level are supported by intentionally awkward and punishing mechanics, resulting in a ludo-narrative aesthetic of defamiliarization commensurate to a grotesque story about subversion and revolt. Echoing the ritualistic cycle of death and rebirth at the heart of carnivalesque aesthetics, The New Colossus is nothing short of an ideological re-invention of the genre.
\end{abstract}

Keywords: game narrative; politics; gender; ability; cyborg; defamiliarization; carnivalesque; Gamergate; Bakhtin; Haraway; AAA; FPS

\section{Shooting Virtual Nazis as Entertainment and/or Politics}

When Grant Tavinor wrote in 2009 that "Nazis, aliens, monsters, zombies, genetically manipulated mutants [fall] somewhat outside the purview of regular morality" (Tavinor 2009, pp. 165-66), he was very carefully establishing a baseline for "legitimate enemies" (Pötzsch and Šisler 2016, p. 14) in digital games. Since the 1980s, "fighting the good war against unequivocally evil Nazi soldiers" (Pötzsch and Šisler 2016, p. 7) has been a prevalent trope in digital games, where "the 'Good War' narrative is taken to a hyperbolic extreme" (Salvati and Bullinger 2013, p. 163). No game epitomizes this hyperbole better than Wolfenstein 3D (id Software 1992), which not only provided the template for the whole genre of First-Person Shooters (Wolf 2008, p. 156; Pinchbeck 2013, p. 9), but also set the bar for portrayals of fighting Nazis by eventually pitting its player character BJ Blazkowicz against a cybernetically enhanced Adolf Hitler.

Given how unquestionably the Wolfenstein games have always been "anti-Nazi games" (Wolf 2008, p. 209), it is poignant that the latest entry in the long-running series, Wolfenstein II: The New Colossus (MachineGames 2017), provoked the outrage of "Alt-Right" sympathizers. Moving beyond the by-now commonplace heated discussions on user forums and Reddit, The New Colossus became the target of coordinated attacks on social media (Maiberg 2017) and was review-bombed (Moseman 2017), i.e., subjected to mass-postings of strategically negative reviews to "punish" the developers. 
While the young Swedish developer team at MachineGames downplayed the political aspects of their product, publisher Bethesda Softworks was remarkably vocal about not only its continuing support of both the game and its developers, but also about the game's timeliness and topicality, aggressively emphasizing its political dimension (Batchelor 2017). While some commentators characterized this as nothing more than clever marketing, large parts of the games press and some independent developers expressed their support, often contextualizing the game within the increasing acceptance of Alt-Right demagogues by right wing mainstream politicians (Gaynor 2018).

Considered in the light of the political controversy surrounding it, reviews of the game show that-just like any other serious cultural product-its merit as an element of a socio-political debate and as a work of art are inextricably entangled. Doubts about the sincerity of The New Colossus's anti-totalitarian message are frequently connected with aesthetic value judgments, such as that its "serious commentary seems ultimately written in service of its pulpy action" (A. Robertson 2017). This ambivalence and insecurity about The New Colossus's goals and achievements are echoed where it has been considered solely on its qualities as a game. Even when going so far as to call it exemplary of what AAA games—the game industry's equivalent of a Hollywood blockbuster movie-in 2017 should be doing (Francis 2017; McKeand 2017), the praise lavished upon it bespeaks some reservations about "vexing decisions-small issues with writing, the anticlimactic pacing, over-reliance on simplistic stealth, and the unnecessary decision to pull control from the player-[which] hold Wolfenstein back from its potential status as the quintessential modern First-Person Shooter" (Brynard 2018).

The argument presented here is that the ambivalence evoked by the "vexing decisions" of The New Colossus's design team is intentional, as a way of exploring "political themes and topical issues [which] rarely find their way into AAA blockbusters" (Batchelor 2017). I show how the ludic and narrative elements of the game are carefully orchestrated to make them (as MachineGames formulate their design philosophy) "pull in the same direction at the same time" (Graft 2014) to create a First-Person Shooter that critiques its legacy, its conventions, and even its players, without breaking with any of them.

The argument I present here is that The New Colossus is not quite "an exercise in deconstructing" (Evans-Thirlwell 2017) its characters and its generic roots, but rather one of defamiliarizing them. ${ }^{1}$ The New Colossus takes the treatment of World War II and Nazi ideology from the camp of its predecessors (Wolf 2008, p. 156) to an aesthetic of the "grotesque, cathartic, beautiful, horrible and shocking" (Smith 2017), or, more precisely, the carnivalesque in the sense of Mikhail Bakhtin. Following earlier studies into the use of the carnivalesque as an aesthetics of defamiliarization in digital games (Klevjer 2006; Majkowski 2014), I show how MachineGames reappropriate the genre conventions of First-Person Shooters (e.g., a white male protagonist killing hundreds of literally faceless enemies) by deconstructing and reconstructing them: the masculinity, whiteness, and able-bodiedness of the player character are problematized and reframed in the light of contemporary sensibilities about gender, race, and ability. Similar to the pre-modern tradition of the carnival, The New Colossus calls its own (generic and societal) foundations into question through provocation, grotesquery, and inversal, not staging a coup or revolution, but fulfilling a necessary function as both an outlet for dissatisfaction and a stimulation of discussions. In analogy to the carnival's imaginary, which centers upon the ritualistic cycle of death and rebirth (Bakhtin 1984, p. 164), The New Colossus sets in scene the symbolic death and-importantly—rebirth of First-Person Shooter (in the following: FPS) conventions as something

1 I opt for the term defamiliarization instead of the closely related terms alienation and e(n)strangement because each of them stands in a distinct, often medium-specific tradition and is alternatively used in a very general or a very specific sense (Pötzsch 2017). For the purpose of the argument presented here, defamiliarization is meant as a "making strange" of signs in the spirit of Shklovsky's ostranenie (Shklovsky 2017), but also older traditions going back at least to first generation English Romanticism (Bogdanov 2005), i.e., the notion of using elements of a system in a manner that makes them individually perceptible, moving them from something appearing as natural to something strange and inviting reflection. One additional reason for privileging Shklovsky in this article is that his theories on distancing effects have been shown to be (despite some differences) both historically and argumentatively compatible with Bakhtin's (Emerson 2005). 
which (similar to the pre-modern governmental structures the original carnival targeted) only change over time and as a part of slow societal shifts in awareness and sensibilities.

The following argument proceeds in six steps: First, I situate The New Colossus both as a game dealing with history and as a cultural artefact of a specific historical period. Second, I point out the paratextual markers that indicate the intentionality of the observed elements. Third, I introduce the basics of Bakhtinian thought and its application to games. Fourth and fifth, I analyze the narrative (foregrounding the character constellation, the plot structure, and the metaphorical dimension) and the game mechanics, showing how they correlate to create calculated ambivalence. Finally, I discuss two key sequences of the game to show how carnivalesque aesthetics tie together the overall design of The New Colossus. The goal is to expose the construction principles behind the game's "vexing decisions" through a close reading of its narrative and gameplay, and to show that, while MachineGames might not be familiar with the theories of Bakhtin and Haraway I draw upon, their game unquestionably shows their investedness in discussions about games and gender, race, and ability.

\section{Aesthetics for Challenging Gamer Masculinity}

Given that The New Colossus is a game about Nazis and has been a point of contention in current political debates about far-right issues, the fact that I chose an aesthetic instead of a historical angle to discuss the game might need some explanation.

First, The New Colossus takes a different approach than most other historical, war-themed games: Instead of building upon historical accuracy as a starting point from which to allow players the creation of their own counterfactual histories (Rejack 2007; Apperley 2018), The New Colossus puts players into a linearly scripted counterfactual history (J. Robertson 2017). The New Colossus is set in the 1960s of an alternate timeline where Nazi Germany won World War II and colonized the United States. This major departure from actual history is introduced in the predecessor, The New Order, through a narrative strategy that ties the player's perspective to that of the player character, US special forces soldier BJ Blazkowicz. In The New Order's initial stages, BJ is seen to suffer head trauma, and when he wakes up from a coma after ten years, the world around him has changed dramatically, in ways that the player discovers together with BJ. In The New Colossus, BJ is firmly established as a Resistance member, hunted by the world-wide Nazi regime as a terrorist, and executing attacks that rival the enemy's in scale-including detonating a nuclear warhead in a populated area. The goal of BJ's violence is exclusively political, as he and his Resistance cell, the "Kreisau Circle," strive toward mobilizing the American public into civil unrest or even outright revolution against the Nazi occupiers.

Reviewers expressed concern that the game's lack of realism might be standing in the way of a critical engagement with politics (E. Smith 2017). In historical game studies, though, the kind of counterfactuality employed in The New Colossus has been characterized as a strategy that on the contrary encourages "reflection because it deals specifically with the representation of history" (Apperley 2013, p. 190). By not "only" deviating from history through gameplay, but choosing a counterfactual historical starting point, such games are "encouraging reflection on historical rigor by providing a platform for dialogue around plausibility" (Apperley 2013, p. 190). In other words, despite its departure from historical events, The New Colossus obviously deals with history (and especially fascism and colonialism), and there would be many ways to approach the game from within the wide field of historical game studies with its pluralist research interests and methods (Chapman et al. 2016), as well as postcolonial game studies (Mukherjee 2017). ${ }^{2}$

2 The complex position in game history that The New Colossus occupies would well be worth studying. Considering it as a part of a genealogy, it is the direct descendent of Wolfenstein $3 D$, and hence not only generically, but prototypically a First-Person Shooter. The continuity within the Wolfenstein series is complicated by the fact that it had its origin already in an often ignored 2D action adventure, Castle Wolfenstein (Muse Software 1981), and that the full title of the newest game Wolfenstein II: The New Colossus indicates that MachineGames' first game, Wolfenstein: The New Order (MachineGames 2014), is considered rather a reboot than a sequel within the series (although on the narrative level, it continues the story of BJ Blazkowicz from the earlier games, rudimentary as it may have been). Put in a production context, it is reported that for their first 
The choice of an aesthetic over a historical approach is based on two observations. The first observation concerns the tone of the game's engagement with history, which is nothing short of farcical. The scene that encapsulates this best shows an aged Adolf Hitler trying out actors for a film he is producing, an auto-hagiography praising his terminal victory over evil. He has written the script himself, secluded in the new Nazi headquarters on Venus-the only place he is thought to be safe from BJ. Hitler is portrayed as frail and confused, making an entrance in dirty underwear and a bathrobe, only to throw up on the carpet. It is simultaneously frightening and ridiculous to see Hitler give a confused speech while waving a gun around, standing next to a pool of his own vomit in his nightdress, and eventually killing one of the actors in a flight of rage (Figure 1) before being led away like a child. This ambivalence in the portrayal of Hitler (as well as historical events and characters in general) situates the game less in a historiographical than a satirical tradition-one which, as I argue, is drawing heavily on the carnivalesque tradition. ${ }^{3}$

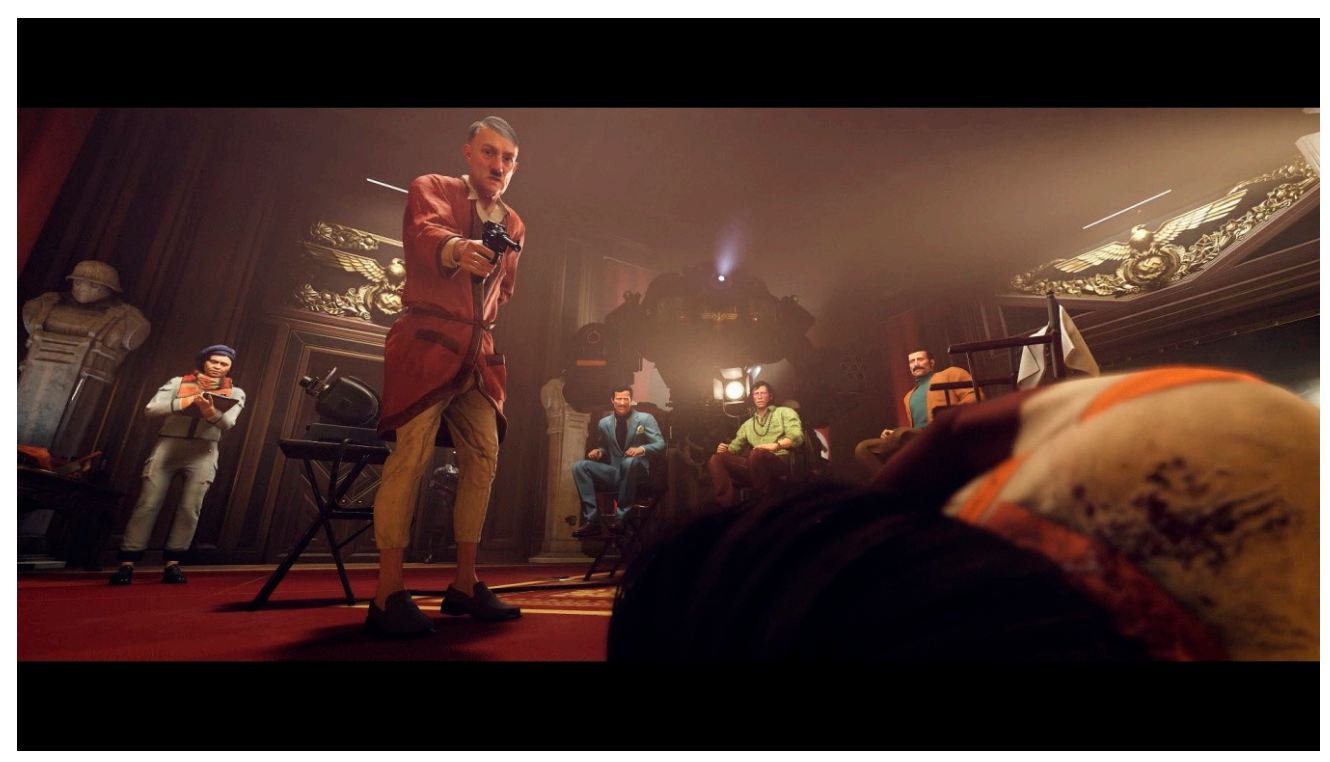

Figure 1. Hitler in his bathrobe killing an actor.

The second observation is, as Pete Hines of Bethesda put it, that it is "pure coincidence that Nazis are marching in the streets of America this year" (Batchelor 2017). Even though the game engages throughout with "the awful Nazi regime's twisted ideology" (McKeand 2017), and although there are some hints at contemporary world politics to be found-one of the many newspaper clips scattered throughout the gameworld alludes to the Trump administration (Evans-Thirlwell 2017)-I argue that those elements are the backdrop of the game's political discourse, not its center. Once we look beyond the facile assumption that the game caused controversy because of its portrayal of Nazism, we can see that most criticism leveled against it can be traced back to departures from the standards of the FPS genre.

game, The New Order, "developer MachineGames was tasked with making Nazis feel like meaningful enemies instead of warmed-over cannon fodder" (A. Robertson 2017). Given that it was the first production of MachineGames (Graft 2014), expectations were low-in the words of one reviewer, "a dumb shooter with dumb characters-Duke Nukem vs fascists" (McKeand 2017)—which helped the critical and commercial success of the game's careful balancing act between paying homage to Wolfenstein 3D's iconic status and gentle updates to gameplay, production values, and cultural sensibilities. All these factors were conducive to MachineGames' ability to produce a risky project like The New Colossus, and receive the support of their publisher.

3 Another notable departure from the majority of war-themed historical games is that, whereas those gloss over the fact that they are less reflections of actual history than of their mediated representations-what Salvati and Bullinger call metonymically "BrandWWII" (Salvati and Bullinger 2013)—The New Colossus thematizes the importance of media for our cultural imaginary of history, from the film-shoot to omnipresent advertisements, newspapers, and TV shows. 
The New Colossus deviates from generic norms even more than its already slightly unconventional predecessor: Often hopelessly outnumbered, even BJ Blazkowicz, the epitome of the gung-ho shooter character, needs to resort to stealth in The New Colossus, all the more so because he no longer recovers fully from the wounds he has suffered, has his health-value permanently lowered, and even starts the game in a wheelchair. Not only mere fans of the game, but professional reviewers criticized these design decisions, remarking that "the stealth mechanics are stale and superficial" and that players "have already completed about half the game by the time it decides to let you feel truly powerful" (Brynard 2018). Even to professionals, it is apparently unthinkable that making the FPS player feel disempowered might be one of The New Colossus's design goals. The game's narrative points in this direction, as it not only portrays BJ as disillusioned and suicidal, but relegates him to the role of a brute enforcer, a part player within a multi-ethnic cast led by strong, idiosyncratic female characters (J. Robertson 2017) - a treatment of game characters less in line with conventions of AAA than what Dyer-Witheford and de Peuter call "games of multitude" (Dyer-Witheford and Peuter 2009, p. 188).

These two observations about the game's take on history and genre-that The New Colossus is actively pursuing ambivalence in its portrayal of history and breaks with conventions of its genre in ways that leave even professional reviewers alienated-become even more telling when the time of production is contextualized not only within world politics, but within game(r) culture.

The New Colossus entered production right after the release of its predecessor, i.e., in the summer of 2014, the origin of the \#Gamergate movement. By now well-documented and chronicled (Mortensen 2015), \#Gamergate marks a paradigm shift in the public discourse about games. The driving force behind it were fears of loss of identity and privilege of "hardcore gamers"-predominantly white, cis-gender males from the global north, often lifelong players of "real games" (Shaw 2013), such as the "violently gory and technologically complex genre of FPS titles" (Dymek 2012, p. 39). Their fear of disenfranchisement was not new; what changed in the summer of 2014 was both the extent to which whole networks of gamers acted upon their convictions by harassing prominent Others, and that previously latent Fascist sentiments became verbalized, with far-right mass-media such as Breitbart.com providing prominence and public support (Mortensen 2015, p. 2).

Hardcore gamer identity and masculinity discourses have historically been strongly entangled. As Newman's study of early home console culture shows, already in the 1970s, "[v]ideo games would invite players to act out fantasies of masculine empowerment" (Newman 2017, p. 67). Despite the by-now established statistical diversity of players of digital games, the development and especially marketing of games has carried forward a culture in which a "male player is generally addressed [ ... ], even when female main characters are represented (typically sexualized)" (Newman and Vanderhoef 2014, p. 381). The marginalization of the "obscure subcultural" (Voorhees 2012, p. 92) hardcore gamer created a problematic identity for them:

Hardcore video game culture privileges an idealized hegemonic masculinity even while that culture contends with a stereotype of the gamer-the name for someone seriously invested in hardcore PC, Xbox 360, or PlayStation 3 games in particular-as immature, lazy, and boyish. Helen Thornham (2009) argues that in response to the infantilizing of digital games, gamers rationalize and normalize their play to establish an aura of legitimacy.

(Newman and Vanderhoef 2014, p. 383)

As such, even though they are doubtlessly the "dominant fundamental group" recognized and given "'spontaneous' consent" within the hegemony (Lears 1985) of gamer discourse, the identity of hardcore gamers is plagued by (self-)doubt and needs constant affirmation of its values. It is therefore unsurprising that hardcore FPS games have been identified as a primary arena for affirming masculinity and patriarchal ideals. By positioning "the masculinized gamer as a defender of patriarchal subjectivity" (Spittle 2011, p. 323), especially horror and military themed games have fostered the development of aggressive (and gendered) player communities (Dyer-Witheford and Peuter 2009, pp. 82-85). 
With \#Gamergate, some self-declared hardcore gamer spokespeople reinterpreted these latent, historically grown traditions of unreflected identity politics in AAA games as an unavoidable fact and vehemently requested that they be affirmed and propagated-a position that must have provoked the politically sensitive developers at MachineGames. Already committed to developing a historically and military themed FPS, they bent the rules of the genre as far as possible in ways that foreground the stereotypes hardcore gamers were taking for granted, yet without completely deviating from the established formulas. Science-Fiction-themed FPS in the tradition of System Shock (Looking Glass Studios 1994) have frequently bent the genre rules to a greater degree. To have its desired effect, the game needed to work as a FPS and still appeal to its core target audience to be played by them, because "the nuances and aesthetics of the contemporary video game medium are imperceptible to most parts of society" (Dymek 2012, p. 51), i.e., only they are able to understand the significance of The New Colossus's iconoclasm. I show that carnivalesque aesthetics allows the game to offer up ridicule and confrontationalism with a gesture of jest, a "yes, but" resolution of conflicting positions. Before exploring this aesthetic strategy, though, it seems necessary to point out how The New Colossus invites players to read it as a serious and critical text.

\section{Invitation to Play: Paratextual Markers of Difference}

As mentioned already in the Introduction, even overwhelmingly positive reviews of The New Colossus voice a certain degree of puzzlement over the grotesque narrative, perceived inconsistencies, and some unpleasant game mechanics. I propose to read the inconsistencies and perceived flaws (especially, as I argue in Section 6, the much-criticized stealth system) of The New Colossus as intentional elements meant to provoke the players. I argue that such a reading of the game is justified because its immediate, primary paratexts—its title and the end-credits song—situate the game as a political, subversive cultural product, and act as very visible signposts inviting a deep (and benevolent) reading of the game.

"The New Colossus" is the title of Emma Lazarus' sonnet engraved into the foundations of the Statue of Liberty. The source of the oft-quoted "Give me your tired, your poor//Your huddled masses," the sonnet is emblematic for American values of a bygone past, above all the promise of shelter and fairness to refugees. Read before the background of the game's narrative, Lazarus' title forms an ironic counterpart to the Nazi-ruled USA of The New Colossus's imperialism and forced integration into a Germanic cultural domain. Within the greater cultural context of the game's time of release, though, the irony extends to the xenophobic, nationalistic tendencies on the rise worldwide, from tensions in the EU as a reaction to the Syrian refugee crisis to Brexit and, maybe most of all, the Trump Administration's Mexican border-wall and no-tolerance position on immigration.

While the title opens the political dimension of the game, its end credits hint at its intended mode of interpretation. The end credit's soundtrack is a cover version of Twisted Sister's "We're not gonna take it," in a performance credited to the apocryphal band Veilröth, featuring influential extreme Metal guitarist Fredrik Thordendal of the Swedish band Meshuggah. The song's origin, history, and interpretation create a network of contradictions that all but enforces critical engagement: Lyrically a protest song for teenagers against the suppression by adults, "We're not gonna take it" gained additional prominence and momentum at the time of its release in 1984 through Twisted Sister's band image and its provoking play with gender stereotypes. Coming from the band's singer, cross-dressing icon Dee Snyder, the rejection of outdated values of propriety and decency gained an additional gender-component. How easily the actual subject matter and gender subtext can be ignored is nowhere more apparent than in the song's use by the Trump presidential campaign: ostensibly intending it to be nothing but a general declaration of dissent, Trump played the song at the end of his rallies-a practice ultimately prohibited by Snyder (Diaz 2015). The cover version at the end of The New Colossus takes the glam/punk song and re-interprets it with down-tuned staccato guitars and a completely new middle section as a challenging, progressive-rock soundscape. The on-the-nose choice of music is counteracted by the unexpected interpretation in a way that eludes facile explanations to the same degree as the 
song's history of interpretation and use. In other words, the choice of music mirrors the controversial, highly context-dependent configuration The New Colossus has been situated in by its developers, and the re-interpretation of it parallels the game's reformulation of its genre traditions. If one follows the reading of the game proposed here, "We're not gonna take it" thus becomes a message from game developers to \#Gamergate's conflation of gamer identity and reactionary ideology.

\section{Carnivalesque Aesthetics and Games}

The carnivalesque has long been established as a means for confronting hegemonic structures. Mikhail Bakhtin's reflections upon the carnival practices of the late Middle Ages and Renaissance come out of his studies of François Rabelais's satires. Bakhtin shows how the pre-modern humoristic sensibilities of Rabelais' texts (with their explicit treatment of bodily functions and physical excesses) are, on the one hand, rooted in old folk traditions of the carnival and have had, on the other hand, aesthetic influence on modern realism. Bakhtin argues that Rabelais' texts are prime examples of the carnivalesque, "an aesthetic of mockery, inversion and excess, grown out of the body-based and grotesque elements of popular culture in the middle ages and the renaissance" (Klevjer 2006).

The carnivalesque tradition is, to Bakhtin, part of an older, more general practice of societal resistance, the "culture of laughter," where the calcified relationships of power between groups and classes are ridiculed and, as a result, called into question. In laughing about authority, its claim to formulating universal truths is undermined: "The opposition between the unofficial culture of laughter and the official culture of order thus appears to be one between a culture of ambivalence and a culture of monovalence" (Lachmann 1988, p. 130). The ambivalence created by this kind of laughter produces a crisis with the possibility of "a shift of world orders. Laughter embraces both poles of change, it deals with the very process of change, with crisis itself. Combined in the act of carnival laughter are death and rebirth, negation (a smirk) and affirmation (rejoicing laughter)" (Bakhtin 1984, p. 127). In other words, ridiculing an authority and its power-structures is seen as productive and empowering by Bakhtin, the fertile ground of a ritualistically reoccurring cycle of change.

In the context of late Medieval community founded on religious principles, the festivities of the carnival allow for a radicalization of the principles of the (counter-)culture of laughter. In the carnival, "dogma, hegemony, and authority are dispersed through ridicule and laughter" (Lachmann 1988, p. 130). In this "spectacular feast of inversion and parody of high culture," the power of laughter is amplified to allow for a "complete withdrawal from the present order" (Lachmann 1988, p. 118). However, Bakhtin observes, the carnival itself is merely an emblematic prototype of the carnivalesque, which therefore is less a practice situated in a specific historical setting "as it is a certain kind of spirit, an aesthetic of vulgar, popular gaiety which is identifiable in the writings of Rabelais. Central to this spirit is the appreciation of what Bakhtin labels grotesque realism, an attitude that turns the vulgarity of excrement, orifice and bodily dismemberment into a joyful affirmation of the materiality of the body" (Klevjer 2006).

As an artistic style, this grotesque realism opposes what Bakhtin terms classical realism: instead of the celebration of timeless virtues and constant truths that dominates classical texts, grotesque realism "concentrates on the fleeting nature of both the body and the social order in which the body is currently positioned" (Majkowski 2015, p. 31). Grotesque realism operates with a repertoire of motives revolving around physicality and reversals of positions or polarities: "All the images of carnival are dualistic; they unite within themselves both poles of change and crisis: birth and death [ ... ], blessing and curse $[\ldots]$, praise and abuse, youth and old age, top and bottom, face and backside, stupidity and wisdom" (Bakhtin 1984, p. 126). By "combining what should not be combined, presenting moments of humiliation, describing carnal erotic and gastric excess as well as mutilation and various deformations," grotesque realism presents the human body "as constantly connected to the world and other bodies, always unready, becoming, giving birth, dying, and being recreated" (Majkowski 2015, p. 31).

Bakhtin's concepts have been applied to digital games by some scholars, with different results. Probably the most opposed takes on the carnivalesque potential of games are those of Rune Klevjer and 
Tomasz Majkowski. Discussing exclusively First-Person Shooters and connecting Bakhtin with Victor Turner, Rune Klevjer describes the carnivalesque in games as a liminal contribution to a ritualistic negotiation between parts of a culture. The First-Person Shooter genre combines, according to Klevjer, a "spectacular and modern-ritualistic celebration of modern violence and power" with "cultural contradictions, parody and play, and does not seem to be entirely defined by traditionally militaristic and imperialist ideologies," which makes him propose that "the FPS-aesthetic delineates a liminal space of techno-romantic power-play, a space where dominant ideologies are celebrated and negated" (Klevjer 2006).

Klevjer is, however, skeptical about the actual manifestation of this potentially carnivalesque ambivalence, which he underscores by injecting Turner's idea of liminality into Bakhtin's theory. Turner distinguishes famously between traditional rituals, which create liminal spaces, and modern practices that resemble them, yet are something different, i.e., merely liminoid, because they are "most often commodities which the consumer can choose to buy into or not" (Klevjer 2006). To complicate matters, morally imperative cultural forms (such as the satire) can transcend from this stage to one of pseudo-liminality, which is infused with value-arguments. To Klevjer, the "FPS-Adventure absolutely qualifies as such a "pseudo-liminal" form of play. It is a strictly commodified and industrially manufactured piece of entertainment software, providing an artificial realm of ritualistic performance that is both nostalgic and hyper-modern" (Klevjer 2006). In an involved rhetorical move, Klevjer refocuses the carnivalesque element of digital games from the game artefact to the player. He maintains that the

grotesque element renders the mastery of the player visible, immediate and spectacular. Carnival is the perfect ingredient in techno-fetishist forms of play, augmenting the simulated power fantasies. The abstractness and invisibility of modern technological power is transformed into a simulated realm of mythic heroism and violence, where it suddenly becomes something concrete, magical and terrifying. There is no doubt, then, that the run-and-gun First Person Shooter is inherently conformist and affirmative as a cultural form [ ... ]. (Klevjer 2006)

Thus, even while Klevjer sees in FPS games a potential to "open up to the modern individual a playful space of potentially transgressive practice" (Klevjer 2006), he categorically denies them the ability to be carnivalistic in the same way that Bakhtin sees in Rabelais and Dostoevski.

Tomasz Majkowski has taken the exact opposite position in a number of recent papers, where he describes digital games as a privileged locus of the carnivalesque. His starting point is a view of digital games as inherently parodistic, in the sense of a "self-awareness of storytelling." Both game designers and players have to be highly aware of generic conventions of both games and narratives, because "to successfully navigate the game, the player needs to identify the situation they are in and, moreover, predict the possible narrative or mechanic solutions. This ostentatious clarity additionally increases the tension between game and its references, thematising its own object, that is the ways of constructing and carrying out the storylines" (Majkowski 2014, p. 2). To Majkowski, this is not only manifest in the worldbuilding and narrative, but extends to the selection practices inherent in setting up the rule systems of ludic simulations. He sees in them parodistic (or, to go with a term not explicitly used by him, but suggested in his description, caricaturistic) strategies already in the act of translating the disorganized multiplicity of reality into the rule-bound interactions of gameworlds: "The very mechanism of the successful construction of a video game stems from parody: it relies on isolating from the chaos of reality some clear and easily distinguished rules and forging them into a coherent system governed by stated, larger-than-life rules" (Majkowski 2014, p. 1).

Majkowski concedes that the treatment of bodies in games is generally different from in the carnivalesque tradition. Both for reasons of gameplay and social acceptance as an entertainment commodity, "the lower stratum of the body" and its functions (especially fornication and defecation) are almost absent. The foregrounding of the human body in its imperfections and changeability that dominates grotesque realism can, however, still be found in digital games, in avatar-based games even 
at their very core: "At the centre of the gameplay there is therefore a body: of the hero, sometimes present on the screen in its entirety, perceived from the outside, and sometimes cut into pieces and fragmentary (and so degraded), in a perspective suggesting a bodily sameness of the player and the hero" (Majkowski 2014, p. 3). Additionally, the "lower stratum" of the body emphasized in traditional grotesque realism is alluded to in the hypersexualized and hypertrophic design of female and male bodies in games (Majkowski 2014, p. 4). Taken together, the "various grotesque deformations of bodies in mainstream, high-budget video games, such as over-muscled male protagonists, hypersexual women and hideous or inhuman enemies, as well as the strange obsession with producing photorealistic settings, fall firmly into this aesthetic" (Majkowski 2015, p. 27).

Majkowski identifies three common tropes that resonate with the carnivalesque: First, the perfectibility of the protagonist through improved equipment and leveling up is an expression of the carnivalesque emphasis of the constant becoming of the human body. Second, the segmentation of (mostly enemy) bodies draws attention to body parts and their no longer actualized functions, similar to the explicit treatment of (especially the lower) body in carnival practices. Third, the hierarchy of enemies that gets climbed and toppled (by overcoming regular foes, mini-bosses, and bosses) is carnivalesque in itself, because "the hero fulfils their carnivalesque mission in deconstructing the hierarchical order, exposing its most important defect: the seeming difference in quality between two ends of the social ladder is in actuality a difference in quantity" (Majkowski 2015, p. 34).

Where Klevjer re-interprets the gameplay of digital games as rituals and therefore concludes that only in transgressive play, games can be the locus of carnival, Majkowski stresses the difference between the tradition of the carnival and the carnivalesque aesthetics of grotesque realist fiction: "Games seem to be closer to narrative forms which, as Bakhtin writes, are more carnivalesque than a carnival per se. Therefore, some phenomena, clearly observed in street festivities, are problematized or presented as metaphors. [... ] On the level of narrative, the collective body finds its equivalent in the polyphony and heteroglossia of the novel, that is in the equality of various points of view and socially rooted languages which are not given into the regime of ideological speech and official hierarchy" (Majkowski 2015, p. 36). The parodistic foregrounding of the game narrative's artifice allows for the carnivalesque potential of games to unfold: "In this way, for the duration of the game, the player is freed from conventional rules governing the everyday and placed in a space in which they can act in a manner usually forbidden: above all they can murder and destroy and devote themselves to limitless, positively-valued devouring" (Majkowski 2014, p. 3).

In this, Majkowski addresses the performative dimension of the play act, yet arrives at a different conclusion than Klevjer. To Majkowski, violent gameplay in action games is not so much subjugated to a cultural hegemony of techno-fetishism as it "erodes moral and social authorities and in the atmosphere of a merry but cruel carnivalesque laughter [ . . ] it opens up a space of free destructive action, whose aim seems to be a temporary, but significant empowerment of the player, who in the world of seriousness answers to social rules. The obscene laughter has healing qualities, and an openly parodist, non-compromising game seems to be a substitute for holy days, loosening the corset of rules and allowing for their self-restitution in the atmosphere of merry play" (Majkowski 2014, pp. 8-9).

Majkowski's argument relativizes Klevjer's to a certain degree, especially when one considers that the latter's insistence on established carnivalesque practices runs counter to Bakhtin's observation that these are always subject to constant developments and reinterpretations. ${ }^{4}$ Bakhtin already distinguishes between the carnival proper and carnivalesque strategies, which can be deployed very flexibly, which is not only expressed in Bakhtin's writings, but forms their basis. While his work masks as a description of a folk culture tradition, it is a critique of Stalin-era cultural hegemony, allowing

4 As Renate Lachmann emphasizes, the carnival is to Bakhtin one specific step in the tradition of the culture of laughter, not its "pure" or final form: "Bakhtin attempts to document how the experience of ambivalence in folk culture always derived from a conflict with agelastic [laughter-averse] culture. This conflict took place in such a way that the concrete expressions invented by folk culture always corresponded to the official forms prevailing at the time" (Lachmann 1988, p. 132). 
Bakhtin to circumvent censorship and to formulate a tongue-in-cheek deconstruction of homogenizing Stalinist discourse (Lachmann 1988, pp. 116-20).

Klevjer's second point of contention, the friction between the counter-cultural potential of the excesses of digital games and their situatedness in an extension of the military-industrial complex, is where The New Colossus deviates from the patterns Klevjer identifies in the FPS tradition. In the next section, I show how the game reflects upon the technology-driven action of the FPS genre by problematizing discourses of masculinity and ability through the destabilizing ridicule Bakhtin describes.

\section{Breaking with the Conventions of the American Aryan Hero}

In Section 3, I argue that the ambiguous paratexts challenge players to assume an underlying subtext in all of The New Colossus and thus engage with it critically. This section reads the game's narrative level in this fashion, outlining the very clear positions it takes on issues that other games (and its own predecessors) have long ignored.

The themes of fascism, oppression, racism, and, in general terms, othering, become tangible already in the diversity of its cast of characters. That despite this diversity the player character is still white, hyper-masculine, and cis-gender might at first seem like a concession to player demographics and genre conventions. Given how radically this character is exposed to criticism and deconstructed, not the least through situating him among very diverse characters, the opposite seems to be the case. Instead of flirting with ideas of white, male supremacy, the game continuously exposes Nazi rhetoric ${ }^{5}$ and central values of fascist and supremacist ideology such as masculine virility (Spackman 1997). One particularly obvious instance is when an SS-officer in a conversation with player character BJ Blazkowicz compliments him on his "very Aryan face," putting the finger on one of the ironies of the game series', the fact that the great American hero incorporates every ideal of the Nazi master-race (see Figure 2). As Edwin Evans-Thirlwell remarks in one of the most insightful early analyses of the game, The New Colossus is caught in a Foucauldian differential of power that resembles that of its protagonist: "To take up arms against a regime is therefore to risk perpetuating that logic, as MachineGames' portrayal of BJ as a latent fascist acknowledges" (Evans-Thirlwell 2017).

In the previous game, The New Order, BJ indeed starts out as a perfect image of Aryan body ideals. At the beginning of the The New Colossus, though, he is on the brink of death, and throughout half of the campaign, his derelict body is basically kept alive by machines. In the initial gameplay sections, the player controls BJ in a wheelchair, where he is weakened and his range of motion limited (see Figure 3). This creates a striking contrast to the traditions of body representations in FPS games, which rely on stark othering in their ableist, heteronormative image of the player character: In the depiction of opponents, FPS games overwhelmingly employ aesthetics of the abject and the uncanny, dehumanizing or demonizing the other (Brock 2011; Spittle 2011; Carr 2014). The avatar body, on the other hand, is mostly unseen, yet implied to be near ideal or perfectible, allowing for affirmation of values and a feeling of security: "By donning another corporeality, that of the avatar, players can experience just what a superhard and agile body can do-perform a hyperviolent masculinity in a space that allows them to contest the waning dominance of white heteronormativity, free from the disapproving eye of the 'other,' or the unwelcome gaze of the gay male" (Burrill 2008, p. 79). ${ }^{6}$

5 Not the least because of how widespread and diversified Nazi strategies of denigrating and dehumanizing people rhetorically are (Casmir 1968), its treatment in The New Colossus could be the subject of a paper of its own. For an exemplary discussion of one strategy, the "kill the rats" rhetoric, see (Francis 2017).

6 This emphasis of heteronormativity and hypermasculinity is incidentally reminiscent of Fascist gender performativity, which was driven by (besides factors such as reproduction politics) a fear to be perceived itself as queer (Herzog 2011, p. 73). 


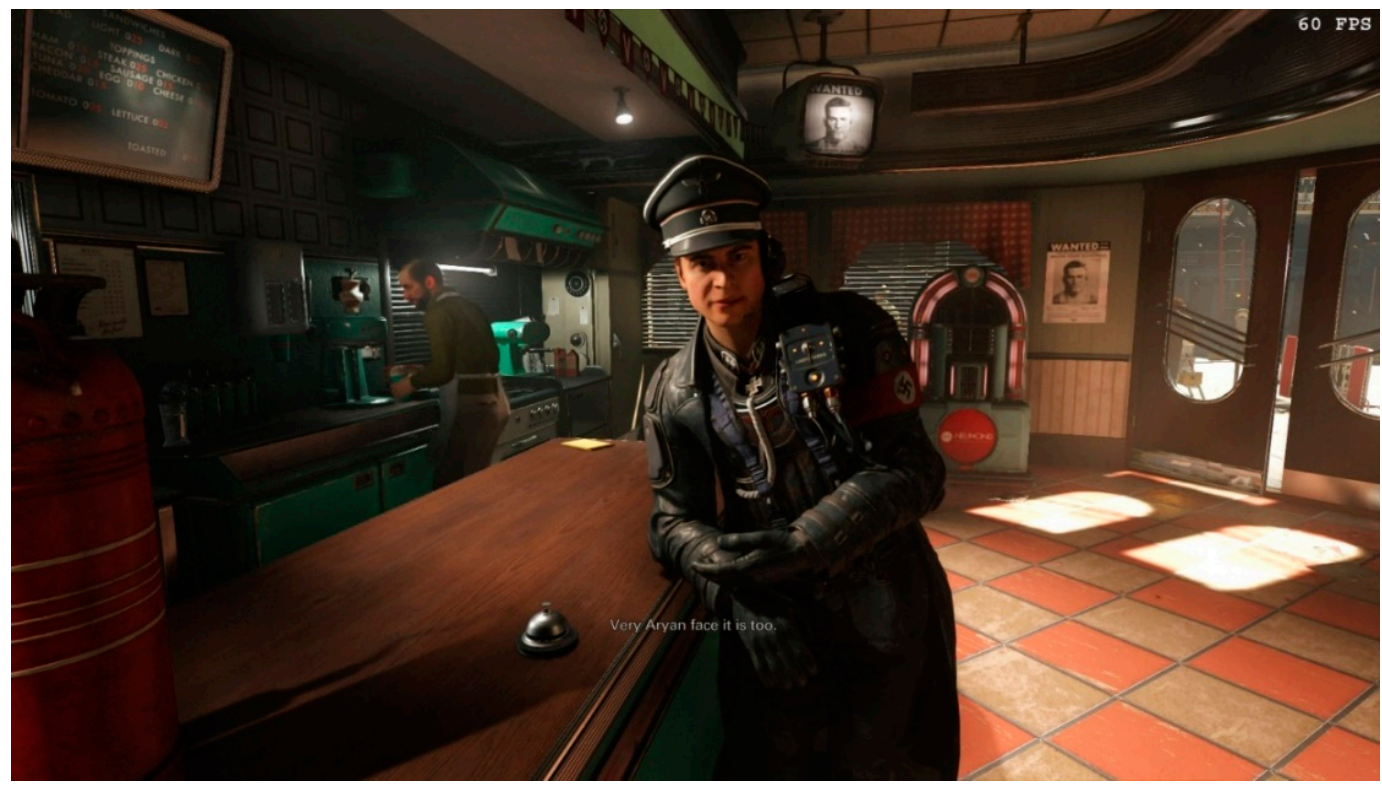

Figure 2. A Nazi officer complimenting the player character upon his Aryan facial features.

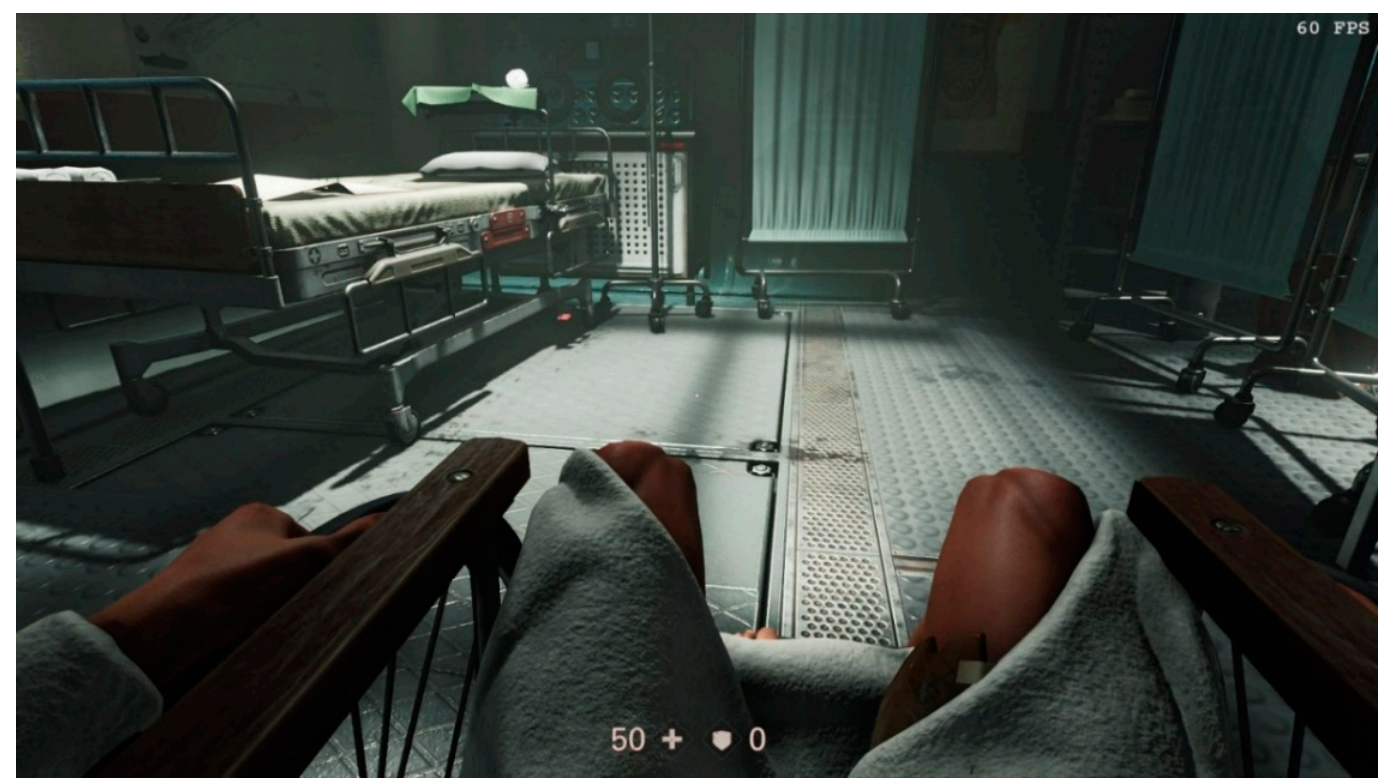

Figure 3. Hero in wheelchair, bathrobe, and catheter.

The decision to start the game by depriving BJ Blazkowicz of his able-bodiedness is more than a gameplay twist on FPS conventions (which I discuss in the next section), it caricatures the promise of improvement and perfectibility implicit in the standardized alternative corporeality of hardcore games. Instead of offering the player an avatar who is better than them in basically every way and can act as a foil for projections of masculine power fantasies, The New Colossus re-contextualizes BJs body in the alternative corporeality of disability. Disability studies emphasizes "the active transformation of life that the alternative corporealities of disability creatively entail" (Mitchell and Snyder 2015, p. 2), i.e., the ingenuity and tenacity it takes to navigate a society built upon implicit standards of able-bodiedness (Siebers 2008). It would be naive to assume that putting BJ in a wheelchair was a realistic simulation of disability, but it does not have to be; it radically runs counter to the player expectations of an FPS avatar body as hyper-able and lets players experience being in a physical environment that does not accommodate one's corporeality. 
That BJ remains a viable FPS avatar despite the limitations to his mobility is due to technology. His dependence on technology is very apparent in the big picture, where he is able to move first in the wheelchair and then a power armor, before eventually having his head attached to a vat-grown Nazi supersoldier-body, in a procedure that combines advanced surgery and cabbalistic science-magic. Emphasizing the technological basis of movement of the FPS avatar through the wheelchair stresses not only an overall dependence on tools-because once he is equipped with weapons and traps, BJ is very well capable of dealing with his situation. It also suggests that The New Colossus's avatar is always a cyborg, first in a mundane way of technological augmentation, then a militaristic power-fantasy, and eventually a more fundamental vision of near-immortality through putting a consciousness into a new body. The realization that $\mathrm{BJ}$ is always already a cyborg draws attention to the fact that the "archetype of the cyborg warrior has acquired a fundamental position within the FPS genre" (Klevjer 2006). Cybernetic technologies are indeed central to countless games of the genre, and in many variations, from the iconic power-armors of Half-Life (Valve 1998) and Doom (id Software 2016), to more ostensibly realistic near-future and far-future militaristic visions of armored infantry in games such as Call of Duty: Advanced Warfare (Sledgehammer Games 2014) and Titanfall (Respawn Entertainment 2014), and even voluntary and involuntary extensive body-modifications in Deus Ex (Ion Storm 2000) or Quake 4 (Raven Software 2005). Klevjer highlights that the trope of the cyborg externalizes and stylizes a dependency on technology that is inherent in digital games and the act of playing them: "The fantasies performed are fantasies about abilities, made possible by the representational and procedural powers of the computer. In this sense, therefore, all computer game avatars-and all computer game players-are cyborgs" (Klevjer 2006).

Klevjer's consequential (albeit radical) suggestion of extending the cyborgism of the avatar to the player resonates strongly with the close association between the FPS avatar's able-bodiedness and the masculinity discourses of hardcore gaming discussed in Section 2. As "discourses of disability and ability connect with other aspects of subjectivity including ethnicity and gender" (Carr 2014, EN 8), BJ's disability puts a spotlight on his masculinity, which both through the vicarious cyborgism identified by Klevjer and the discursive masculinization of hardcore gamers suggests connections to the gender identity of the players. ${ }^{7}$ Put differently, the way in which BJ Blazkowicz is a cyborg in The New Colossus stands less in the tradition of the techno-fetishist, hyper-ableist masculine power-fantasies Klevjer identifies as typical of FPS games than in that of Donna Haraway's feminist and post-humanist “Cyborg Manifesto" (Haraway 1991).

Haraway's essay takes its point of departure in the historical moment of a "radical change in American white heterosexuality" which coincides with a blurring of "the boundary between physical and non-physical" (Haraway 1991, p. 153). Just as sexual identity is discussed in the early 1990s as all-encompassing and infinitely more complex than previously considered, technological visions of the future turn out to have been realized in unexpected ways that have not yet been noticed by society. Instead of a utopian step of technologically driven evolution producing unambiguously new human-machine hybrids, the reality of cyborgs is one of "ubiquity and invisibility," in which they are "as hard to see politically as materially. They are about consciousness—or its simulation. They are floating signifiers" (Haraway 1991, 153). Radicalizing the idea of the cyborg to a much farther degree than even Klevjer, Haraway states that her "cyborg myth is about transgressed boundaries, potent

7 Jordan Wood's analysis of The Binding of Isaac—something of a polar opposite of a AAA FPS—shows an even more clear alternative to the heteronormative and hypermasculine stylization of the avatar. Wood argues compellingly for how the ordeals of a naked pre-teen boy in "randomly generated levels of psychosexual, scatological horror" (Wood 2017, p. 222) are challenging stereotypes of masculinity to the point where they "represent queer becoming" (Wood 2017, p. 218). Full of "radical rejection of heteronormative safety" (Wood 2017, p. 225), the game negates with its rogue-like structure heteronormative narratives of linear progression and improvement (Wood 2017, p. 224) and couples gains in Isaac's powers to "highly visible, grotesque alterations to his corporeality" (Wood 2017, p. 224). Although The Binding of Isaac is more radical in its departure from norms, it is remarkable how similar the strategies employed in The New Colossus are in their connection of masculinity and ability discourses with scatological and grotesque imagery. 
fusions, and dangerous possibilities which progressive people might explore as one part of needed political work" (Haraway 1991, p. 154).

As I show in detail further down in this section, The New Colossus's protagonists are exactly this, a group of progressive people who risk everything to effect political change. Transgressing boundaries of race, class, and ability, and disregarding conventions of gendered behavior, they personify the danger of "impurity" feared by Nazi ideologues. They are a prototypical example of the macroscopic dimension of Haraway's cyborg, a communal body not unlike the Hobbesian Leviathan. What distinguishes this type of communal union from other models is that it is formed by neither necessity nor blood "but by choice, the appeal of one chemical nuclear group for another" (Haraway 1991, p. 155). In Haraway's ideal, groups are united by "affinity, not identity" (Haraway 1991, p. 155)—an ideal that is made topical throughout The New Colossus's portrayal and discussion of the founding principles of respectively Resistance and Nazi communities.

It might seem far-fetched to invoke complex post-structuralist concepts of the cyborg in the discussion of The New Colossus, as if I were suggesting that MachineGames actively engaged with Bakhtin, Haraway, or Klevjer. More likely than not, this was not the case. However, the sensibilities with which complex topics such as intersectionality and community building are anchored in the game can be outlined more clearly before the background of these theoretical and ideological frameworks-especially in their conjunction, which is mirrored in the closely intertwined themes and motifs of the narrative.

Only in the light of theories of cyborgism and the association of player identity and generic treatments of masculinity, the permutations of BJ's body become coherently meaningful. Giving the avatar a disability allows the game to show that, similar to any alternative corporeality, digital play needs technological support to function according to expectations. Exchanging the wheelchair for the power suit comes down to replacing a mundane, obvious, and clumsy prosthetic for a (in game conventions) more common, easier to ignore, elegant prosthetic which quickly become transparently normalized as a part of the player character's body. However, The New Colossus finds ways of having the power armor draw attention to itself when BJ fruitlessly tries to hide it away under clothes. When it rips through the heavy leather jacket, it obviously resists the illusion of normalcy, giving visibility to its otherness compared to a common human body. When BJ re-attains the semblance of normalcy through a synthetically crafted body created in Nazi laboratories, his post-human status becomes less visible, yet still far from hidden, as the connection between his head and the vat-grown body is clearly visible above his collar. To complete the post-human, post-gender argument, BJ's previously central virility is no longer performed on-screen in the love-making that was prominent in The New Order, but transcended into the pregnancy of his girlfriend Anya. Especially after the body-graft, his sexuality goes unmentioned, at least hinting at the possibility that the artificial body might be effectively sexless. While the cyborg-dimension of BJ's body certainly is a metaphor for the player-avatar relationship as Klevjer posits, it is not one of friction-less identity or empowerment. At no point is BJ the invulnerable Übermensch of Aryan propaganda and FPS stereotype, but rather its reversal and ironization. ${ }^{8}$

As mentioned in the beginning of this section, BJ's weakness and humanity become even more noticeable because of the diverse cast of characters he is embedded in. While rather one-dimensional on their own, as a rather large ensemble, they form a kaleidoscope of personalities.

No-one in this game is fully rounded as a character-in isolation, each is too shallow to match our own complexities-although each exhibits their own defining characteristic. Irene Engel has the apathy, Anya the empathy, Set the curiosity, Super Spesh the paranoia, Sigrun

8 This affects not only BJ: In one of the two possible versions of the gameworld, the Fergus timeline, Fergus Reid receives a prosthetic arm which will not cooperate, and is identified by him as female. Combined with his constant clashing with Resistance leader Grace Walker, this lets Fergus emerge as an alternative to BJ's acceptance of post-human or at least gender-positive thinking. Fergus is the caricature of the war hero caught in a pointless performance of masculine stereotypes in the face of damage to his physical integrity and a subversion of his androcentric world view. 
Engel the naivety, BJ's father owns the hatred and fear, BJ himself is consumed by loss and sadness. Together, they form what most would consider to be some of the key facets of humanity—for better or worse. (J. Robertson 2017)

Beyond their personalities, the many ethnicities, beliefs, and body-types represented by them makes The New Colossus an example for what Dyer-Witheford and de Peuter call "games of multitude" (Dyer-Witheford and Peuter 2009, p. 188), i.e., digital games that go out of their way to not privilege a certain, usually American or European, white ethnic identity. Even though it focuses on cis-gender characters, the game puts questions of gender front and center. Together with his physical integrity, BJ's masculinity in terms of social roles and behavioral patterns is a central locus of defamiliarization of genre tropes.

This discourse already begins in The New Order, where BJ becomes a member of the Kreisau circle, a Resistance cell led by a woman, Caroline Becker. Caroline's paraplegic body puts her initially in a wheelchair and later in the power armor BJ "inherits" from her after her death. BJ follows therefore quite literally in Caroline's footsteps, but just as he is happy to serve under her para-military leadership, he makes her his spiritual leader after her death, talking to her in his thoughts in what amounts to prayers for guidance. Both physically (as wearer of the power suit) and spiritually (as temporary leader of the Resistance cell), BJ tries to fill the void left by her. The power suit proves to only be a makeshift solution for his problems, and his leadership cannot live up to Caroline's example, so he gladly steps down as soon as another leader is available: Grace Walker, an African-American Resistance fighter whose politics combine patriotism, feminism and Marxism.

The female leaders are only one way in which The New Colossus reverses the stereotyped gender-roles commonly found in mainstream entertainment. The most important characters in relation to $\mathrm{BJ}$ are women, his enemy, his leader, and his lover, yet all of them in ways that do not conform to clichéd roles. BJ's Nemesis is SS-General Irene Engel, a cruel, sadistic Nazi-stereotype whose obsession with the American soldier has unmistakably sexual undertones. Instead of portraying her as hysteric, pining, or with other behavioral patterns traditionally coded as expressive of female sexuality, she is an aggressive sexual predator. Several times throughout the course of The New Colossus, BJ is exposed naked and vulnerable in front of Engel, who even commits acts of sexual violence against him, "kissing" him with Caroline's head after decapitating her, and simulating oral rape with a gun (see Figure 4). In a series of very different breaches of convention, Grace Walker, the eventual leader of BJ's Resistance cell, is introduced by giving an exposition of the horrors of war for the population of a city subjected to a nuclear attack, and doing so while breastfeeding her infant child and smoking. Her anti-patriarchal stance is poignantly comprised in the end of her initial conversation, when BJ unthinkingly compliments her courage by calling her actions "ballsy." This provokes a diatribe from Grace in which she eloquently juxtaposes the vulnerability, frailty, and ugliness of testicles to their metaphorical grandeur. BJ's girlfriend Anya is initially introduced as his nurse in The New Order, and while she already in the first game develops into a fierce combatant in her own right, the sequel shows her as a third-trimester pregnant Valkyrie equaling BJ in every aspect. Throughout the campaign, she is hinted at performing acts of heroism equivalent to BJ's, but off-screen, an unsung heroine, coming only to the fore when really needed. She does so in the very end, as discussed in the final section of this article.

The game goes so far as to make BJ symbolically disavow patriarchal order. BJ's childhood is shown in flashbacks to have been dominated by the violence of his father, an immigrant to the US who denied his Eastern-European roots to the point where he allied himself with the Nazi oppressors and sold out his wife to them for personal gain. When BJ kills his father, he does so in great part to avenge his mother, who had not only remained faithful to her Polish heritage, but also to her Jewish faith. BJ choses his mother's ethnic and religious heritage for himself, to the point of marrying her self-sufficient, new-woman mirror image Anya in the end. 


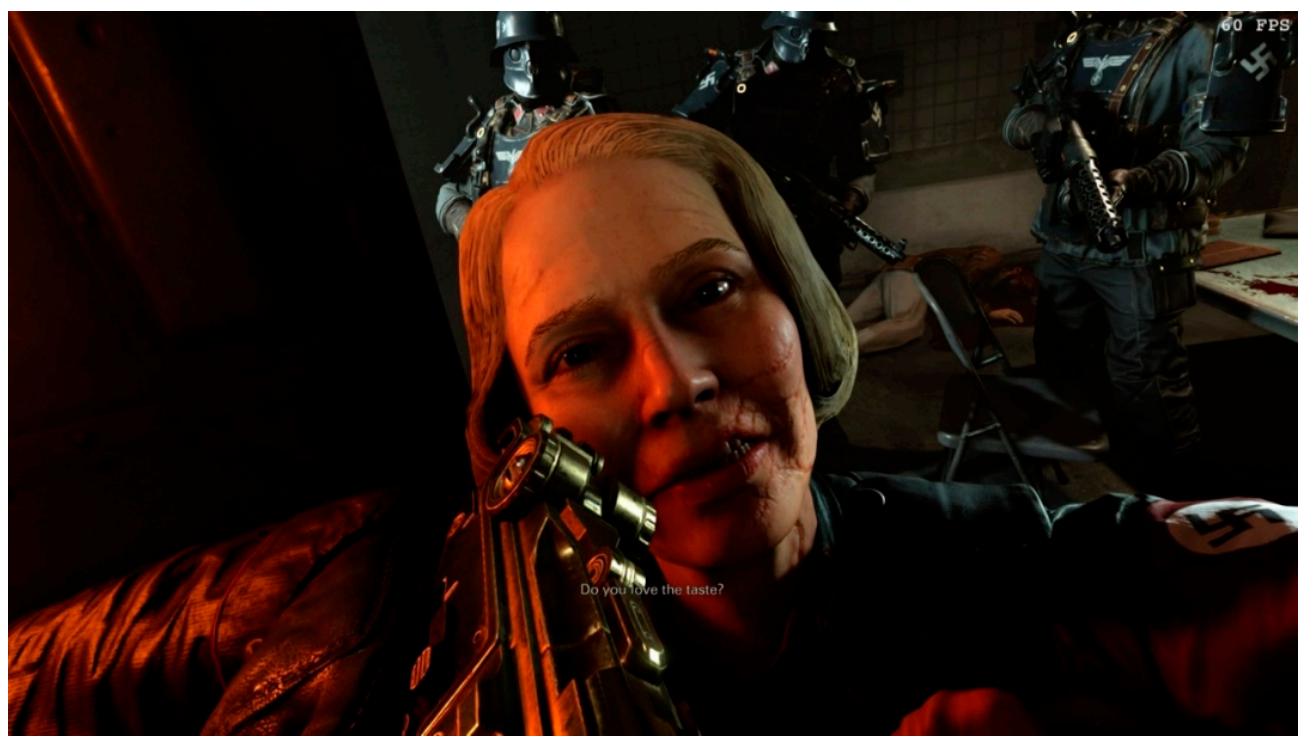

Figure 4. Irene Engel's sexually charged assault on BJ Blazkowicz.

\section{Mechanics of Withdrawal}

The New Colossus would already be noteworthy if it only offered a critique of the politics of its genre on the level of its narrative, but the game goes further than this. The gameplay mirrors the aesthetic devices of the narrative in exactly the points that critics sometimes perceived as flawed or problematic. Three design decisions particularly stand out in this respect: health management, stealth mechanics, and equipment limitations.

For the majority of the game, the avatar is confined to a wheelchair or artificially empowered by an actuator-driven suit of armor. The wheelchair restricts the player's agility, forcing her to act more strategically and carefully than in a traditional FPS (like the predecessor The New Order), and while movement in the power armor is comparatively unrestrained, it is still clunky and somewhat imprecise. Throughout these sections, the weakness of BJ is signified ludically by halving his maximum health value. Gameplay-wise, this is offset by both the ability to wear armor (and quite a lot of it when wearing the power suit) and temporarily boosting the health-value beyond its maximum value. However, seeing the health counter trickling down to 50 has not only the gameplay function of making the avatar less resilient, but psychologically reinforcing an awareness of the frailty of the human body - a memento mori quite unheard of in the gung-ho world of First-Person Shooters. The physical restrictions imposed on the avatar by, e.g., the wheelchair might be argued to be not carrying any game-extrinsic meaning. Bo Kampmann Walther has argued for what he calls "dynamics of recursivity" (Walther 2007), meaning that game elements always refer first and foremost recursively to the rules governing them. The extra restrictions imposed on the avatarial body through the wheelchair would in this logic be transparent and normalized, because within the ludic structures of The New Colossus, they are no different from all the other artificially imposed constraints typical of goal-oriented play that players submit to in what Bernard Suits calls the "lusory attitude" (Suits 2005, pp. 54-55). The New Colossus, however, does not allow for the naturalization of some game elements (like the wheelchair) because it changes them before repetition could make them conventionalized, and uses the narrative to remind the player of their additional significance.

The stealth mechanics of The New Order drew significant criticism for being clumsy and awkward, if not downright broken. While not a dedicated First-Person stealth game in the tradition of Thief: The Dark Project (Looking Glass Studios 1999), The New Colossus encourages stealthy gameplay in several ways, such as introducing it in tutorial sections and awarding achievements for stealth kills, yet also on a more universal level, given that the high difficulty of fights especially against mini-bosses and bosses makes avoiding open fire-fights often more of a necessity than a stylistic choice. At the 
same time, taking cover and sneaking are implemented without much feedback on the level of the interface, so that detection happens easily and will not be communicated to the player in the efficient and forgiving manner that has become customary in recent stealth games. This results in a stealth feature that is, ironically, as unpredictable, dangerous, and challenging as the fights, often leading to failure in situations that should be simple enough. Some enemies, especially the Zitadelle- and Zerstörer-class robots, can be easily avoided through stealth, making it effectively possible to choose which bosses to fight. The stealth mechanics thus offer at the same time a choice to avoid fighting in a combat-oriented game, characterizing this approach as a valid alternative solution, yet also signaling that this is not the strong suit of the player character or the game. Similar to BJ, the player is forced outside her element by the events of the game, and not offering a perfectly balanced and polished way of dealing with these challenges becomes less of a shortcoming than a ludic analogy to the narrative about limits, challenges, and (dis-)abilities.

The third strategy of The New Colossus that might appear as a shortcoming is the omission of some weapons from the previous game. Missing a sniper rifle, heavy machine gun, and rocket launcher, the second game features a slightly reduced inventory in terms of sheer numbers, which, however, is offset by allowing the fewer weapons to be freely combined with each other in dual-wielding configurations. As with the health and stealth mechanics, this not only has (in this case positive) gameplay ramifications, but results in a procedural rhetoric that exchanges fascist ideals of purity and strength in numbers for strength through diversity. The New Colossus delivers a similar message when introducing its BFG class weapon, the Übergewehr, in only one level late in the game, when the weapon can be found in a research lab on Venus. Only available once, rather cumbersome, effectively overpowered and not very useful in the narrow corridors of the space station, and impossible to keep when leaving the level, the super-weapon becomes an almost useless symbol of the self-defeating nature of "superior force."

The design strategy of withholding or subtracting gameplay is furthermore tied into the history of the series. This is again most easy to demonstrate in direct comparison between the two most recent games in the series. Both feature a playable version of Wolfenstein 3D. In The New Order, it is only one level, which is implemented as a well-hidden Easter-egg quite late in the campaign, and is contextualized as a nightmare in which BJ relives his own past. In The New Colossus, the whole game is implemented as an in-game arcade machine, and completely re-contextualized as a cultural product of the alternate history of the game: entitled "Wolfstone 3D," the game allows the player to control "Elite Hans," a German soldier hunting for public enemy number one BJ Blazkowicz, or, as the Nazi propaganda apparatus calls him, Terror Billy.

As with its general relationship to history, the refashioning of the predecessor as "Wolfstone 3D" allows The New Colossus to attain an ironic distance to the political as well as medial past, which are highlighted and amplified, e.g., by comments of BJ's about the stupendous fidelity of the game's graphics. In the context of The New Colossus' own game mechanics, a subtler difference between the two different re-envisioned Wolfenstein 3Ds appears especially noteworthy: In The New Order, the controls and weapons available to the player in the dream sequence match those of the rest of the game, giving BJ, e.g., the ability to lean around corners, updating the gameplay and making it effectively somewhat easier. In The New Colossus, the rendition of the original game is faithful, even where the gameplay is outdated and the controls less than perfect. The irony of "Wolfstone 3D" is thus heightened by the fact that this version of the game, despite its Nazi reskin, is the more faithful rendition of the original, compared to which the dream sequence in The New Order appears as a power fantasy. Similarly, the previously mentioned chagrin directed at the game's stealth mechanics ignores that the implementation of stealth in The New Order is rather faithful to the actual original game, the 2D action-adventure Castle Wolfenstein, which pioneered this mechanic: "Castle Wolfenstein's legacy can't be overestimated, particularly in regard to its integration of basic stealth elements into its gameplay" (Loguidice and Barton 2012, p. 24). 
A final procedural statement connected to the "Wolfstone 3D" arcade machine is that it is located in the headquarters of the Kreisau Circle, right next to an allied entertainment machine, a pinball with the name "Yes we can!" This machine is, however, out of order, creating another, this time extremely game-specific, commentary on contemporary politics: The machine named after the political leitmotif of the Obama-era is no longer accessible, cannot be engaged with anymore, and all that remains is a historically revisionist arcade-shooter that draws us in with its technological achievement and graphical fidelity to make the player feel immersed, while ignoring the dubious political message (see Figure 5). ${ }^{9}$ MachineGames' use of an arcade as a metaphor for the shift in the American political landscape between the Obama and Trump administrations, hidden in plain sight in the middle of a mainstream digital game, is a perfectly elegant display of game design mastery.

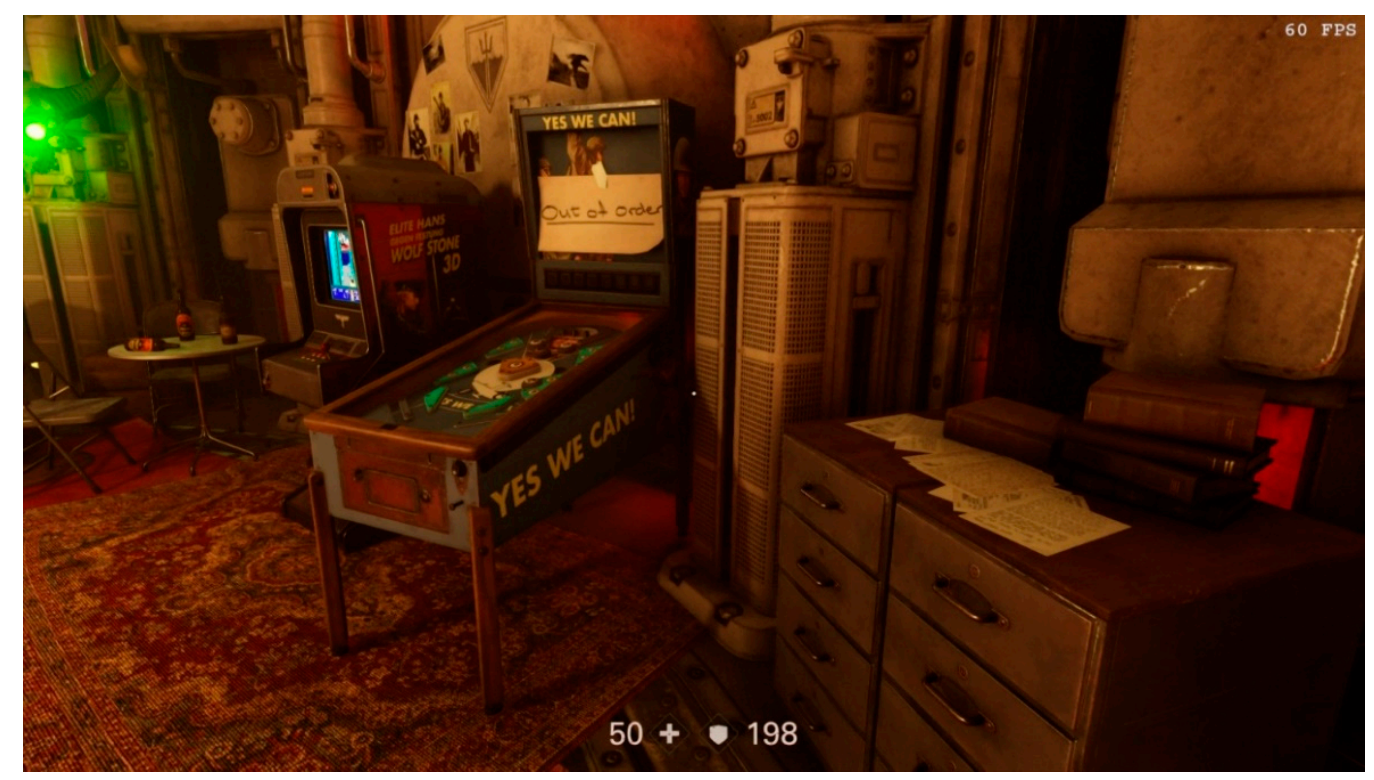

Figure 5. The in-game arcade with the "Wolfstone 3D" and "Yes We Can!" machines.

\section{The Carnivalesque Climax of The New Colossus}

Similar to all carnivalesque, The New Colossus is an expression of counter-cultural thinking (Lachmann 1988), which the game foregrounds by dealing with counter-cultures in its narrative-the Resistance against the Nazi-regime, Marxist and Feminist intellectuals, and beat and rock sentiments-which should not be in any way controversial in our age, yet are set in scene in a way that insinuates contemporary reactionary tendencies.

The New Colossus resists a homogeneous, facile reading of its topics by injecting its narrative with moments of crass humor and grotesquery typical of traditions of the carnivalesque. Some of the characters are so over-the-top-especially conspiracy theorist Super Spesh and communist preacher Horton Boone-as to be caricatures. The specifically carnivalesque dimension of the characters in the game is easiest to demonstrate in Scientist Set Roth's pet, Shoshana. While the hybrid animal with a cat's head on a monkey body is on the one hand a plot device foreshadowing BJ's body-graft, her body is, conceptually speaking, combining generally incompatible realms to produce something "unnatural" which allows reflection on accepted norms and standards. To draw attention to her, the game not only features her prominently in many cut-scenes, her name also appears on the score-board of competitions of the Kreisau-circle (e.g., a shooting gallery). The advertisements for German products and service in the armed forces as well as the "Aryanized" reimaginations of pop music classics (turning

9 For a more in-depth analysis of the context the game puts its "arcade" in, see (Evans-Thirlwell 2017). 
e.g., the Beatles into Die Käfer) are often non-sequitur, throwaway comic relief rather than political commentary, in a similar way as the whole sequence in which BJ auditions for the role of himself in a movie produced by Hitler personally. However, they use key techniques of the carnivalesque like the reversal of hierarchies as well as humor centered around lower bodily functions and excrement.

One character is particularly noteworthy as carnivalesque: Sigrun, General Engel's daughter, stands in a humoristic tradition of painting the female body as grotesque by focusing on her sexuality, her physicality, and her bodily fluids (Rowe 2011). Already at the time of her introduction, her obesity and her sexual appetite are stressed, together with her bookishness and her resistance to control through figures of power, in her case her mother. She is a prototype of the trope of the "unruly woman," which "can be seen as prototype of woman as subject-transgressive above all when she lays claim to her own desire" (Rowe 2011, p. 31). In many instances, Sigrun's obesity, chattiness, and lack of self-control are shown or referenced for comical effect, in sometimes clearly boundary-crossing ways as when she and her lover are interrupted in their lovemaking. However, in a carnivalesque act of reversal, Sigrun becomes the subject of a political discourse in unexpected ways. Grace distrusts Sigrun for being the daughter of a German officer and calls her a Nazi at every given opportunity, until Sigrun eventually physically attacks Grace in an act of helpless defiance. The arguments Sigrun raises in her anger all point toward polemics against minorities: She resists being labeled something she is not, being treated as a lesser being or even less than human-clear references to a fascist rhetoric of subjugation, which she, the daughter of a powerful German Nazi official, should both be immune against and ignorant to. That it is not Sigrun but Grace who relapses into this mindset of (to put it in a reversal of Haraway's categories) identity instead of affinity, is the completion of carnivalesque logic, the reversal of the reversal. Sigrun and Grace have exchanged their social positions for their polar opposites, yet those new positions are not stable and need challenging and possibly revising through ridicule, degradation, and potentially violence.

Finally, there are two sequences in which the carnivalesque is presented in its pure form. The first is BJ's birthday party, which quickly develops into a sequence of drinking-contests, pig-riding, casual sex, fighting, plus puke-and-poop jokes. In addition to the overall grotesquery, there are again several instances of reversals of hierarchy, from the explicit reversal of priorities from fighting for liberation to celebrating BJ's birthday to the pacifist, mentally handicapped Max Hass beating BJ in a fistfight.

The second sequence is the final battle, in which carnivalesque aesthetic is most pronounced. In the pivotal cut-scene, Blazkowicz is saved by his pregnant girlfriend Anya several times in a row, first by single-handedly defeating half a dozen of high-level enemies, before protecting him from an explosion with her body. Stripped of her burnt clothes, splattered in blood, her face a hollow-cheeked mask reminiscent of a skull, Anya straddles BJ below her pregnant body in an imagery typical of carnivalesque ritual birth (Bakhtin 1984, p. 126), with her dual-wielded guns and the oft-mentioned twins in her belly adding the trope of duality to that of reversal of roles and ritual rebirth (see Figure 6). As Bakhtin describes it: "In living carnival images, death itself is pregnant and gives birth, and the mother's womb giving birth becomes a grave. Precisely such images are produced by creative ambivalent carnival laughter, in which mockery and triumph, praise and abuse are inseparably fused" (Bakhtin 1984, p. 164). Anya's selfless protection of BJ is an almost comically out-of-proportion act of heroism which simultaneously characterizes her as the true hero of the story and ridicules not only BJ's, but, by extension, the player's efforts and the genre tropes of the First-Person Shooter, by deflating the final climax both narratively and ludically in a deus-ex-machina-moment. The fight has been won, evil has been defeated, yet the victory falls dramatically flat because it is not earned by player or character in any way. Turning the conventions of dramatic and ludic closure on its head, The New Colossus in its final scene once more challenges its players' preconceptions about their roles in the newest take on the genre maybe most intimately associated with male hard-core-gamer identity. 


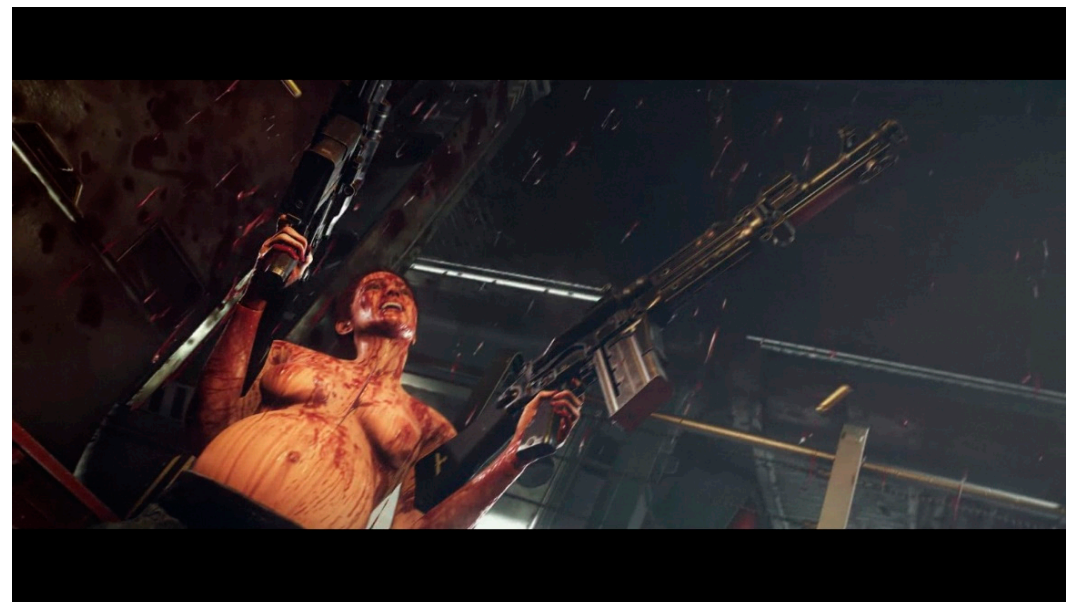

Figure 6. Anya as the carnivalesque female, birthing death.

\section{Conclusions}

The aim of my argument was to show that The New Colossus is definitely not "just" an AAA shooter, and neither a parody nor deconstruction of the genre or its series, but a reaction to contemporary cultural developments presented as a piece of carnivalesque culture in the strict sense: a liminally positioned contribution to a ritualistically conducted negotiation between parts of a culture.

I have argued that reading The New Colossus's departure from traditions of affirmative masculinity in FPS games as a response to a co-option of AAA game development by reactionary hardcore gamers is justified by the time of its development, which coincided with the radicalization of gamer culture in the \#Gamergate events. The New Colossus reverses many of its genre conventions and challenges its core player base, drawing upon the clout of major publisher backing, being situated in a long-running, influential franchise, and following a commercially and critically acclaimed predecessor. The game eschews downright deconstruction of its generic roots in favor of defamiliarization achieved by embracing the Bakhtinian carnivalesque. Not only does the ambiguity of the carnivalesque leave room for conservative players to experience the game without feeling personally attacked in their values and preferences, thus ensuring that the game would not be impalpable to the players it addresses both aesthetically and ideologically. It also allows the norms and implicit value system of FPS games in general to be as idiosyncratic and contradictory as they are. Grotesque elements challenge players and shatter expected coherence into a multitude of ambivalences, and genre tropes get replaced by their reversals, yet all of that happens playfully, temporarily. At the end, everything is as it should be- the Nazis have been temporarily defeated, BJ (and with him, implicitly, the player) is celebrated as a hero-because, after the carnival, everything returns to the way it was.

However, this restitution is only an outward appearance, because the assumed normalcy has been shaken up, has been shown to be a hegemonic construct. The New Order highlights that, as Klevjer has observed, every avatar is a cyborg, and in doing so moves the treatment of cyborgs in the FPS genre from its techno-fetishistic, affirmatively hypermasculine standard to Haraway's vision of the cyborg as an inherently hybridized, multiplicitous subject which rejects and disproves notions of normalcy. Nothing makes this clearer than how misplaced those elements of FPS conventions feel that MachineGames uncritically retain. As one review shrewdly points out, the game's conventions of culturally coding levels of difficulty are conservative and run counter to the game's politics: "Sticking a bonnet on BJ [as a visualization of the lowest difficulty setting] and infantilizing the player by analogy isn't exactly an invitation to explore playing Wolfenstein 2 differently. Even just calling one difficulty setting 'normal' implies the others are deviant. When you're fighting to liberate the country from people who believe in eugenics in a game that celebrates difference and diversity, moralizing the difficulty around the struggle (easy equals lazy/bad, hard equals virtuous/good) feels archaic" (Gach 2017). It says a lot about the sophistication the overall engagement with stereotypes and norms in a 
game when the cultural conventions exposed in the difficulty selection become visible as a misstep against identity sensitivities.

This analysis has demonstrated that The New Colossus manages to connect a high-concept narrative with matching gameplay, and in doing so imbues everything the player does with anti-supremacist subtext: the cripple vanquishes the superhuman, female affinity beats male militarism, diversity trumps strength in numbers, etc. The New Colossus uses the carnivalesque in a fashion that permeates the game as a whole, allowing the player to indulge in inherently ridiculous acts that invite being laughed at as well as laughed about, paving the way for a reflective, responsible engagement with cultural and media history that simultaneously foregrounds the shortcomings and strengths of its own medium. MachineGames thus achieve a rare success: they deconstruct their heritage without destroying or negating it, and give form to an ideal of "affinity, not identity" (Haraway 1991, p. 155) instead of preaching it. Only time will tell if their attempt to lead by example has been fruitful.

Funding: This research received no external funding.

Conflicts of Interest: The author declares no conflict of interest.

\section{References}

Apperley, Tom. 2013. Modding the Historians' Code: Historical Verisimilitude and the Counterfactual Imagination. In Playing with the Past. Digital Games and the Simulation of History. Edited by Mathew Wilhelm Kapell and Andrew B. R. Elliott. New York and London: Bloomsbury, pp. 185-98.

Apperley, Tom. 2018. Counterfactual communities: Strategy games, paratexts and the player's experience of history. Open Library of Humanities 41: 1-22. [CrossRef]

Bakhtin, Michail Michajlovič. 1984. Rabelais and His World. Bloomington: Indiana University Press.

Batchelor, James. 2017. 'It's Disturbing that Wolfenstein can Be Considered a Controversial Political Statement.' Bethesda Marketing Boss Pete Hines Discusses Publisher's Marketing for Upcoming anti-Nazi Shooter. Gamesindustry.biz. Available online: https:/ / www.gamesindustry.biz/articles/2017-10-06-bethesda-werenot-afraid-of-being-openly-anti-nazi (accessed on 6 October 2017).

Bogdanov, Alexei. 2005. Ostranenie, Kenosis, and Dialogue: The Metaphysics of Formalism According to Shklovsky. The Slavic and East European Journal 49: 48-62. [CrossRef]

Brock, André. 2011. ‘When Keeping it Real Goes Wrong': Resident Evil 5, Racial Representation, and Gamers. Games and Culture 6: 429-52. [CrossRef]

Brynard, Alec. 2018. How Wolfenstein II: The New Colossus JUST Misses the Mark. Critical Hit. Available online: https: / www.criticalhit.net/ features / wolfenstein-ii-new-colossus-just-misses-mark/ (accessed on 22 January 2018).

Burrill, Derek A. 2008. Die Tryin': Videogames, Masculinity, Culture. New York: Peter Lang.

Carr, Diane. 2014. Ability, Disability and Dead Space. Game Studies. 14/2. Available online: http://gamestudies. org/1402/articles / carr (accessed on 28 October 2018).

Casmir, Fred L. 1968. Nazi Rhetoric. A Rhetoric of Fear. Today's Speech 16: 15-18. [CrossRef]

Chapman, Adam, Anna Foka, and Jonathan Westin. 2016. Introduction: What is historical game studies? Rethinking History 21: 358-71. [CrossRef]

Diaz, Daniella. 2015. Dee Snider to Trump: I May Not Take It Anymore. CNN. Available online: https:// edition.cnn.com/2015/12/10/politics/dee-snider-donald-trump-twisted-sister/index.html (accessed on 10 December 2015).

Dyer-Witheford, Nick, and Greig de Peuter. 2009. Games of Empire. Global Capitalism and Video Games. Minneapolis: University of Minnesota Press.

Dymek, Mikolaj. 2012. The Video Game Industry. Formation, Present State, and Future. In The Video Game Industry. Edited by Peter Zackariasson and Timothy L. Wilson. New York and London: Routledge, pp. 34-56.

Emerson, Caryl. 2005. Shklovsky's ostranenie, Bakhtin's vnenakhodimost' (How Distance Serves an Aesthetics of Arousal Differently from an Aesthetics Based on Pain). Poetics Today 26: 637-64. [CrossRef]

Evans-Thirlwell, Edwin. 2017. How Wolfenstein: The New Colossus Takes the White Dudebro Hero Apart. Available online: https://www.rockpapershotgun.com/2017/12/28/wolfenstein-2-the-new-colossuspolitics/ (accessed on 28 December 2017). 
Francis, Bryant. 2017. Wolfenstein II: A Good Argument for Games to Get Political. Available online: https:/ / www.gamasutra.com/blogs/BryantFrancis/20171030/308635/Wolfenstein_II_A_good_ argument_for_games_to_get_political.php (accessed on 30 October 2017).

Gach, Ethan. 2017. It Might Be Time to Rethink Difficulty Menus. Available online: https://kotaku.com/it-mightbe-time-to-rethink-difficulty-menus-1820961183 (accessed on 3 December 2017).

Gaynor, Steve. 2018. Wolfenstein Raises the Question: When Did Punching Nazis Become Controversial? Available online: https:/ / www.polygon.com/2018/1/11/16874580/wolfenstein-2-best-video-games-2017-year-inreview (accessed on 11 January 2018).

Graft, Kris. 2014. Being BJ Blazkowicz: Storytelling in Wolfenstein: The New Order. Available online: https:/ / www.gamasutra.com/view/news/218899/Being_BJ_Blazkowicz_Storytelling_in_Wolfenstein_ The_New_Order.php (accessed on 5 June 2014).

Haraway, Donna. 1991. The Cyborg Manifesto. In Simians, Cyborgs, and Women: The Reinvention of Nature. New York: Routledge, pp. 149-82.

Herzog, Dagmar. 2011. Sexuality in Europe. A Twentieth Century History. Cambridge: Cambridge University Press. id Software. 1992. Wolfenstein 3D. Garland: Apogee Software.

id Software. 2016. Doom. Rockville: Bethesda Softworks.

Ion Storm. 2000. Deus Ex. London: Eidos Interactive.

Klevjer, Rune. 2006. Dancing with the Modern Grotesque. War, Work, Play and Ritual in the Run-and-Gun First Person Shooter. Available online: http:/ / folk.uib.no/smkrk/docs/dancing.htm (accessed on 13 July 2018).

Lachmann, Renate. 1988. Bakhtin and carnival: Culture as counter-culture. Cultural Critique 11: 115-52. [CrossRef]

Lears, T. J. Jackson. 1985. The Concept of Cultural Hegemony: Problems and Possibilities. The American Historical Review 90: 567-93. [CrossRef]

Loguidice, Bill, and Matt Barton. 2012. Vintage Games: An Insider Look at the History of Grand Theft Auto, Super Mario, and the Most Influential Games of All Time. Burlington: Focal Press.

Looking Glass Studios. 1994. System Shock. Austin: Origin Systems.

Looking Glass Studios. 1999. Thief: The Dark Project. London: Eidos Interactive.

MachineGames. 2014. Wolfenstein: The New Order. Rockville: Bethesda.

MachineGames. 2017. Wolfenstein II: The New Colossus. Rockville: Bethesda.

Maiberg, Emanuel. 2017. The Alt-Right Thinks 'Wolfenstein: The New Colossus' Is Racist to White People. Available online: https:/ / motherboard.vice.com/en_us/article/mbj9xv/the-alt-right-thinks-wolfensteinthe-new-colossus-is-racist-to-white-people (accessed on 12 June 2017).

Majkowski, Tomasz Z. 2014. Freedom of Destruction and Carnivalesque in Video Games. In Proceedings of the 8th International Conference on the Philosophy of Computer Games, Istanbul, November 3-15; Available online: http://gamephilosophy2014.org/wp-content/uploads/2014/11/Tomasz-ZMajkowski-2014.-Freedom-of-Destruction-and-Carnivalesque-in-Video-Games.-PCG2014.pdf (accessed on 13 July 2018).

Majkowski, Tomasz Z. 2015. Grotesque Realism and Carnality: Bakhtinian Inspirations in Video Game Studies. Edited by Tomáš Bártek, Jan Miškov and Jaroslav Švelch. Brno: Masaryk University, pp. 27-43.

McKeand, Kirk. 2017. What 'Unfiltered Creative Expression' Means for Wolfenstein 2's Depiction of Nazism. Available online: https:/ / www.pcgamesn.com/wolfenstein-2-the-new-colossus/wolfenstein-2-politicalthemes (accessed on 5 September 2017).

Mitchell, David T., and Sharon L. Snyder. 2015. The Biopolitics of Disability. Neoliberalism, Ablenationalism, and Peripheral Embodiment. Ann Arbor: University of Michigan Press.

Mortensen, Torill Elvira. 2015. Anger, Fear, and Games. The Long Event of \#GamerGate. Games and Culture. [CrossRef]

Moseman, Andrew. 2017. People Are Bombarding Nazi-Killing Game 'Wolfenstein II' with Bad Reviews Because It's about Killing Nazis. Available online: https:/ /www.popularmechanics.com/culture/gaming/news/ a28808/people-are-bombarding/ (accessed on 27 October 2017).

Mukherjee, Souvik. 2017. Videogames and Postcolonialism. Empire Plays Back. Basingstoke: Palgrave Macmillan.

Muse Software. 1981. Castle Wolfenstein. Baltimore: Muse Software.

Newman, Michael Z. 2017. Atari Age. The Emergence of Video Games in America. Cambridge: MIT Press.

Newman, Michael Z., and John Vanderhoef. 2014. "Masculinity." The Routledge Companion to Video Game Studies. Edited by Mark J. P. Wolf and Bernard Perron. New York and London: Routledge, pp. 380-87. 
Pinchbeck, Dan. 2013. DOOM. SCARYDARKFAST. Ann Arbor: University of Michigan Press.

Pötzsch, Holger. 2017. Playing Games with Shklovsky, Brecht, and Boal: Ostranenie, V-Effect, and Spect-Actors as Analytical Tools for Game Studies. Game Studies. 17/2. Available online: http://gamestudies.org/1702/ articles/potzsch (accessed on 28 October 2018).

Pötzsch, Holger, and Vít Šisler. 2016. Playing Cultural Memory: Framing History in Call of Duty: Black Ops and Czechoslovakia 38-89: Assassination. Games and Culture, 1-23. [CrossRef]

Raven Software. 2005. Quake 4. Santa Monica: Activision.

Rejack, Brian. 2007. Toward a virtual reenactment of history: Video games and the recreation of the past. Rethinking History 11: 411-25. [CrossRef]

Respawn Entertainment. 2014. Titanfall. Redwood City: Electronic Arts.

Robertson, Adi. 2017. Wolfenstein II Wants to Laugh at the Present without Commenting on It. Available online: https://www.theverge.com/2017/7/27/15958176/wolfenstein-ii-the-new-colossus-gameplaypreview-nazi-punching (accessed on 27 July 2017).

Robertson, John. 2017. Wolfenstein 2's Linearity Is What Makes It a Game Worth Talking about. Available online: https:/ / www.pcgamesn.com/wolfenstein-2-the-new-colossus/wolfenstein-ii-linearity (accessed on 24 January 2018).

Rowe, Kathleen. 2011. The Unruly Woman: Gender and the Genres of Laughter. Austin: University of Texas Press.

Salvati, Andrew J., and Jonathan M. Bullinger. 2013. Selective Authenticity and the Playable Past. In Playing with the Past. Digital Games and the Simulation of History. Edited by Mathew Wilhelm Kapell and Andrew B.

R. Elliott. New York and London: Bloomsbury, pp. 153-67.

Shaw, Adrienne. 2013. On Not Becoming Gamers: Moving beyond the constructed Audience. Ada: A Journal of Gender, New Media, and Technology 2. [CrossRef]

Shklovsky, Viktor. 2017. A Reader. Edited by Alexandra Berlina. London: Bloomsbury.

Siebers, Tobin. 2008. Disability Theory. Ann Arbor: University of Michigan Press.

Sledgehammer Games. 2014. Call of Duty: Advanced Warfare. Santa Monica: Activision.

Smith, Adam. 2017. Wot I Think: Wolfenstein 2: The New Colossus. Available online: https://www. rockpapershotgun.com/2017/10/26/wolfenstein-2-the-new-colossus-review-pc/ (accessed on 26 October 2017).

Smith, Edward. 2017. Why 'Wolfenstein II' Should Embrace Reality, Not Escapism. Available online: https:/ / www.rollingstone.com/glixel/news/why-wolfenstein-ii-should-embrace-reality-notescapism-w496096 (accessed on 10 August 2017).

Spackman, Barbara. 1997. Fascist Virilities. Rhetoric, Ideology, and Social Fantasy in Italy. Minnesota: University of Minnesota Press.

Spittle, Steve. 2011. 'Did This Game Scare You? Because it Sure as Hell Scared Me!' F.E.A.R., the Abject and the Uncanny. Games and Culture 6: 312-26. [CrossRef]

Suits, Bernard. 2005. The Grasshopper: Games, Life and Utopia. Peterborough: Broadview Press.

Tavinor, Grant. 2009. The Art of Videogames. Malden: Wiley-Blackwell.

Valve. 1998. Half-Life. Bellevue: Sierra Entertainment.

Voorhees, G. 2012. Monsters, Nazis and Tangos: The normalization of the first-person shooter. In Guns, Grenades and Grunts: First Person Shooter Games. Edited by Gerald Voorhees, Josh Call and Katie Whitlock. New York: Continuum International, pp. 89-111.

Walther, Bo Kampmann. 2007. Self-Reference in Computer Games: A Formalistic Approach. In Self-Reference in the Media. Edited by Nina Bishara and Winfried Nöth. Berlin and New York: Mouton de Gruyter, pp. 219-36.

Wolf, Mark J. P. 2008. The Video Game Explosion. A History from Pong to Playstation and Beyond. Westport: Greenwood Press.

Wood, Jordan. 2017. Romancing an Empire, Becoming Isaac. The Queer Possibilities of Jade Empire and The Binding of Isaac. In Gaming Representation: Race, Gender, and Sexuality in Video Games. Edited by Jennifer Malkowski and TreaAndrea M. Russworm. Bloomington: Indiana University Press.

(C) 2018 by the author. Licensee MDPI, Basel, Switzerland. This article is an open access article distributed under the terms and conditions of the Creative Commons Attribution (CC BY) license (http:/ / creativecommons.org/licenses/by/4.0/). 